University of Nebraska - Lincoln

DigitalCommons@University of Nebraska - Lincoln

Faculty Publications: Department of Teaching, Department of Teaching, Learning and Teacher Learning and Teacher Education

Education

9-20-2013

\title{
The Gender Trap: Parents and the Pitfalls of Raising Boys and Girls
}

Mardi Schmeichel

Follow this and additional works at: https://digitalcommons.unl.edu/teachlearnfacpub

Part of the Curriculum and Instruction Commons, Gender Equity in Education Commons, and the Teacher Education and Professional Development Commons

This Article is brought to you for free and open access by the Department of Teaching, Learning and Teacher Education at DigitalCommons@University of Nebraska - Lincoln. It has been accepted for inclusion in Faculty Publications: Department of Teaching, Learning and Teacher Education by an authorized administrator of DigitalCommons@University of Nebraska - Lincoln. 
Published in Teachers College Record (September 20, 2013), ID\#17258.

Copyright (C) 2013 Teachers College Record. Used by permission.

Book Review

\title{
The Gender Trap: Parents and the Pitfalls of Raising Boys and Girls
}

\author{
Mardi Schmeichel \\ Department of Educational Theory and Practice, University of Georgia, Athens, Georgia, USA \\ The Gender Trap: Parents and the Pitfalls of Raising Boys and Girls \\ By Emily W. Kane \\ New York University Press, 2012 \\ ISBN: 0814737838 \\ 297 pp.
}

After a long, largely silent hibernation, gender issues have recently reemerged as national topics of conversation in the United States. From accusations of a "war on women" to concerns about "failing boys," debates about the ways in which gender roles are circumscribed by institutions and policies have resurfaced. While the eruption of these discussions is a stark reminder that gender issues are materially real and relevant, it can still be difficult to see how gender forces play out in our daily lives. The Gender Trap: Parents and the Pitfalls of Raising Boys and Girls is an example of the kind of nuanced research that works toward unraveling the complexities of gender as expressed in individual lives as well as larger societal patterns that contribute to problematic assumptions about who girls and boys and women and men must be. Sociologist Emily Kane focuses specifically on the "gender trap" in parenting, which she defines as "a set of expectations and structures that inhibit social change and stall many parents' best intentions for loosening the limits that gender can impose on us" (p. 3). Pointing to the variation and complexity of parents' gender work with children, Kane makes a strong argument for the case that although gender structures are stable and enduring, parents possess the agency to aid their children in avoiding the gender trap, and in doing so can contribute to the dismantling of the social processes upon which gender inequity relies. 
The research Kane presents is a result of an interview study conducted in New England with a group of 42 racially and socioeconomically diverse gay and straight parents of preschool aged children. The introductory chapter provides a cohesive description of both the study and the theories that guided the research and analysis. First, Kane explains her position that gender is socially rather than biologically constructed and then that gender and power are inextricably linked. These complex and potentially divisive arguments are buttressed with effective citational support and are presented in a way that will resonate with those who are familiar with these ideas as well as those who are being introduced to them for the first time. Kane presents a compelling argument for the assertion that the way parents engage with and enact gender with their children contributes to larger social structures in which girls and women are systematically marginalized at both the institutional and personal level, with effects ranging from wage discrimination to domestic violence. Importantly, she notes that while some boys and men may benefit from this power imbalance, their life options are also constrained when gender differentiation is emphasized.

Kane begins the first chapter by describing parents' recollection of their orientation toward a child's gender prior to birth, the first stage in the parenting experience in which "gendered images [of the child] came to life" (p. 28). Across the board, the study participants described preferences for a girl or boy based on strikingly traditional gender norms, reflecting an "anticipatory construction of gender" (p. 29) that Kane argues can be selffulfilling. For example, parents' preferences for sons were characterized as a desire for the family name to be carried on, sharing the father's interest in sports, and a boy's role in protecting sisters. Similarly, preferences for daughters were expressed in terms of shared shopping experiences with mothers and the hope for a strong and long-term emotional bond with a female child. This prebirth expectation of traditionally gendered children is, according to Kane, the first gender trap that parents create for their children, with the potential to shape gender expectations from the child's first breath in a way that will make the traditionally gendered attributes that follow seem "natural."

In the following chapters, Kane presents detailed descriptions and examples of different types of parenting practices. The types she proposes are based largely on parents' different orientations toward beliefs about biological versus socially constructed origins of gender, acceptance or rejection of traditional gender norms, degree of concern about the judgment of others, and recognition of power in relationship to gender. Using these categories of analysis, Kane presents five ways to characterize parents' orientation toward their child's gender: Naturalizers, who perceive gender roles as biologically determined and unproblematic; Cultivators, who view society as the cause of gender differentiation and accept the inevitability of gender differentiation; Refiners, who speak of a combination of biological and social factors in shaping gender identity and express a strong concern for how others - partners, families, strangers, and society-perceive the genderedness of their child; Innovators, who express a significant desire to disrupt problematic gender norms, but who sometimes enable their children to follow the path of least resistance; and finally, the smallest group, Resisters, who are the most oriented to disrupting gender norms but also the most concerned about the social cost their children will pay for straying off the gendered path. 
One of Kane's important conclusions is that many parents were more willing to smooth the rough edges off traditional gender norms for their daughters than for their sons: this was particularly evident in parents' descriptions of wanting to open up career opportunities for daughters beyond traditionally feminine occupations. Kane stresses that opportunities for women to enter traditionally masculinized (and higher status) occupations cannot exist without the dismantling of other gender expectations for women and men. She also argues that the gendered characteristics that parents saw as inevitable and/or preferable for boys-such as aggression and limited emotionality-are components of gender processes that sustain hegemonic masculinity and gender hierarchy in our culture. As such, the lack of willingness to support atypical gender behavior in boys not only limits boys' life options but also reinforces a gender power imbalance.

While this book is highly relevant for parents, it has just as much to offer preservice and practicing teachers of young children, who, like parents, will interact with children in ways that can either reinforce or disrupt gendered expectations. Educators can also possess problematic assumptions about their capacity to interrupt the "inevitability" of the formation of traditional gender identities: Kane's presentation of a range of ways in which children's gender identities are shaped by others can open up the space for educators to consider acting in ways that might lead children "toward less gendered directions" (p. 201). This book is about parents and parenting, but the attitudes toward gender that Kane describes are not held only by parents; they are nested within the social contexts and interactions in which we all participate, parents or not.

\section{About the author}

Mardi Schneichel is an assistant professor of educational theory and practice and affiliate faculty in women's dtudies at the University of Georgia. She is interested in equity issues in education, sport, and gender and the study of discourse. Current projects include a review of the attention paid to neoliberalism in education literature and an examination of the relationship between coaching and teaching in hiring practices for secondary teachers. Her work has been published in Journal of Curriculum Studies, Theory and Research in Social Education, Teaching and Teacher Education, and Journal for Research in Mathematics Education. 